\title{
Localization of tenascin in human skin wounds - an immunohistochemical study
}

\author{
P. Betz ${ }^{1}$, A. Nerlich ${ }^{2}$, J. Tübel ${ }^{1}$, R.Penning ${ }^{1}$, and W. Eisenmenger ${ }^{1}$ \\ Departments of Legal Medicine ${ }^{1}$ and Pathology ${ }^{2}$, University of Munich, Frauenlobstrasse 7a, W-8000 Munich 2, Germany
}

Received June 18, 1992 / Received in revised form October 30, 1992

\begin{abstract}
Summary. A total of 56 surgically treated human skin wounds with a wound age between $8 \mathrm{~h}$ and 7 months were investigated. Tenascin was visualized by immunohistochemistry and appeared first in the wound area pericellularly around fibroblastic cells approximately 2 days after wounding. A network-like interstitial positive staining pattern was first detectable in 3-day-old skin wounds. In all wounds with an age of 5 days or more, intensive reactivity for tenascin could be observed in the lesional area (dermal-epidermal junction, wound edge, areas of bleeding). In wounds with an age of more than approximately 1.5 months no positive staining occurred in the scar tissue. In conclusion, for forensic purposes, positive staining for tenascin restricted to the pericellular area of fibroblastic cells indicates a wound age of at least 2 days. Network-like structures appear after approximately 3 days or more. Since tenascin seems to be regularly detectable in skin wounds older than 5 days, the lack of a positive reaction in a sufficient number of specimens indicates a wound age of less than 5 days. The lack of a positive reaction in the granulation tissue of wounds with advanced wound age indicates a survival time of more than about 1.5 months, but a positive staining in older wounds cannot be excluded.
\end{abstract}

Key words: Tenascin - Wound age - Immunohistochemistry

Zusammenfassung. In 56 chirurgisch versorgten menschlichen Hautwunden mit einem Wundalter zwischen 8 Stunden und 7 Monaten wurde Tenascin immunhistochemisch dargestellt. Erstmals war Tenascin in einer 2 Tage alten Wunde perizellulär um Fibroblasten nachweisbar. Netzwerk-artige, positiv reagierende Strukturen traten im Wundgebiet frühestens nach einer Überlebenszeit von 3 Tagen auf und waren in Hautwunden, die älter als 4 Tage waren, regelmäßig anzutreffen. Mit zunehmendem Wundalter war eine Abnahme der Reaktivität für Tenascin im Granulationsgewebe feststellbar und in den ältesten untersuchten Hautwunden (Wundal-

Correspondence to: P. Betz ter 2,5 bzw. 7 Monate) war kein Tenascin mehr außerhalb des üblicherweise anfärbbaren Strukturen zu beobachten. Der perizelluläre Nachweis von Tenascin belegt somit ein Wundalter von mindestens ca. 2 Tagen, netzwerk-artige, positiv anfärbbare Strukturen im Wundgebiet ein Wundalter von mindestens ca. 3 Tagen. Die regelmäßige Nachweisbarkeit von Tenascin ab einem Wundalter von ca. 5 Tagen gibt bei einer ausreichenden Anzahl von untersuchten Präparaten und Fehlen einer entsprechenden Reaktion Hinweise auf eine Überlebenszeit von unter 5 Tagen. Mit zunehmendem Wundalter sinkt die Reaktivität des Granulationsgewebes für Tenascin und eine positive Reaktion deutet auf eine Überlebenszeit bis ca. 1,5 Monate hin, eine längere Nachweisbarkeit kann jedoch nicht ausgeschlossen werden.

Schlüsselwörter: Tenascin - Wundalter - Immunhistochemie

\section{Introduction}

Wound repair is a series of biological processes involving cellular proliferation, migration, differentiation, and tissue remodeling by the synthesis of structural components of the extracellular matrix such as various collagen subtypes.

However, proteins of the extracellular matrix are not only important for advanced structural remodeling of the tissue, but are also involved in the early phases of wound healing as previously shown for fibronectin [13].

Tenascin is a glycoprotein of the extracellular matrix with a six-armed structure [9] which gave rise to the term hexabrachion. According to previous findings, tenascin has been isolated from various sources leading to a variety of synonyms such as myotendinous antigen, glioma mesenchymal extracellular matrix antigen, brachionectin, $\mathrm{Jl}$ and cytotactin [21].

Tenascin interacts with fibronectin $[10,18]$, supports the adhesion of a variety of cell types including fibro- 
blasts and endothelial cells [5], appears to act as a cell adhesion molecule in particular in the central nervous system [17], and seems to exert immunomodulatory activities [25].

Tenascin is produced by cultured fibroblasts and mesenchymal tissues [21] and is often co-localized with fibronectin, but its occurrence is much more restricted than that of fibronectin [7]. It is found in normal skin in association with epithelial and endothelial cells. Immunohistochemical studies provide evidence for positive staining of the papillary dermis immediately beneath the basal lamina, within the walls of blood vessels, and in smooth muscle bundles of the musculi arrectores pilorum. Strong reactivity can also be found around the cuboidal cells of the basal layer of sweat gland ducts $[19,26]$.

Since a time-dependent appearance in experimental wound healing has been shown [11, 21, 23], this study was performed to investigate whether the immunohistochemical localization of tenascin may be useful for the time estimation of human skin wounds.

\section{Material and methods}

A total of 56 human skin wounds (surgical wounds, stab wounds and lacerations after surgical treatment) with a wound age between $8 \mathrm{~h}$ and 7 months were investigated. Specimens were obtained at autopsy within a postmortem interval of less than 3 days. Subjects had died in traumatic events (car accidents, falls, homicides) and their ages ranged between 15 and 92 years (average age 54 years). Only subjects without malnutrition or severe diseases which could have an influence on wound healing, such as cancer or metabolic disorders, were selected for this study. According to clinical reports no substances which could influence wound healing, such as glucocorticoids or cytotoxic agents, had been administered during therapy.

From each skin wound at least 2 specimens were fixed in $4 \%$ PBS-formaldehyde solution and then embedded in paraffin wax. Sections (thickness of 2-3 $\mu \mathrm{m}$ ) were prepared, and after enzyme pretreatment, tenascin was visualized using a monoclonal antibody (Locus-Genex, Helsinki, Finland) according to the ABC-method [14].

Undamaged skin from the same subjects and specimens without the inclusion of the primary antibody were used as controls.

\section{Results}

\section{Undamaged skin}

In normal skin, a strong positive reaction for tenascin was found in the walls of blood vessels, muscle bundles of the musculi arrectores pilorum, nerve bundles, and the basal cell layer of skin appendages, in particular in sweat gland ducts and in papillary layer of the dermis adjacent to the basement membrane. Strong reactivity was also observed around the bulb of hair follicles.

\section{Skin wounds}

Positive staining for tenascin in the wound area was first detectable around fibroblastic cells in skin wounds approximately 2 days old. The development of network-like

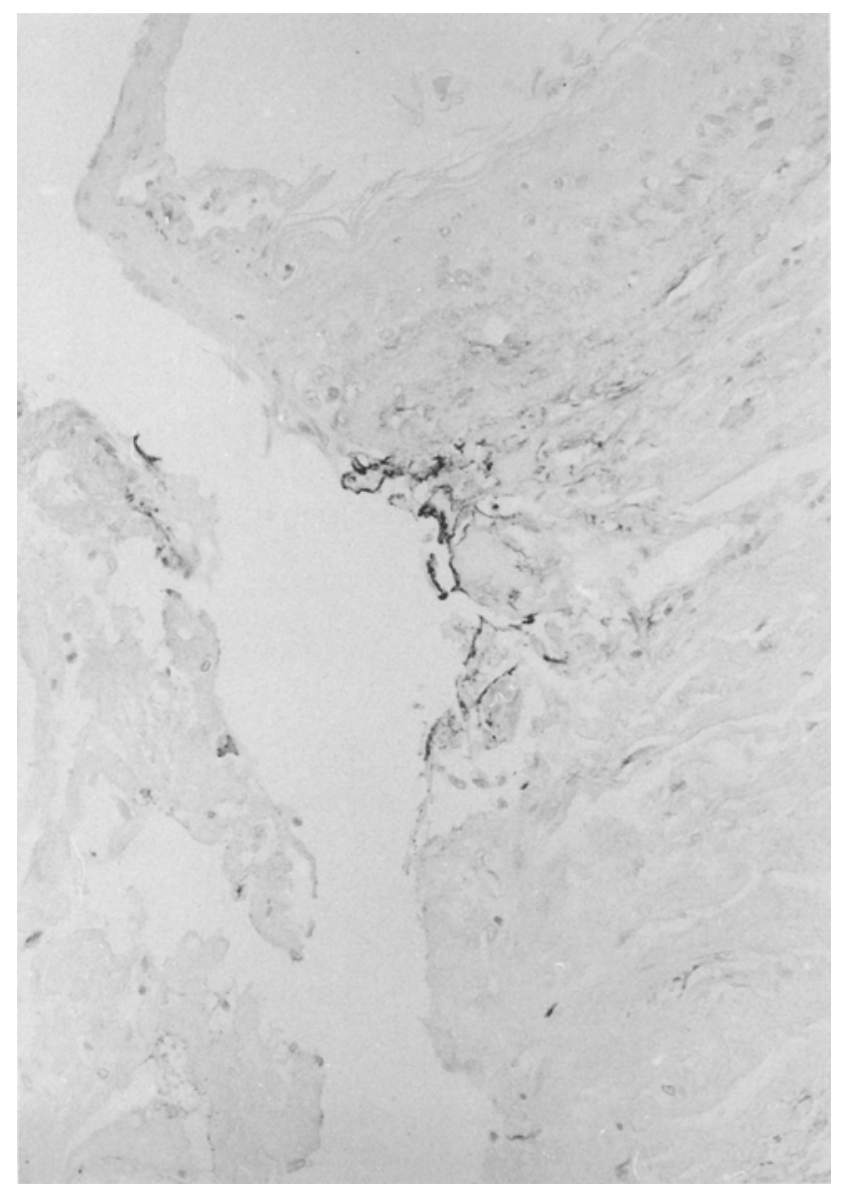

Fig. 1. Wound edge of a 5-day-old skin wound; beginning formation of network-like structures positively staining for tenascin (paraffin wax, $240 \times$, ABC-method)

structures positive for tenascin could be localized in the lesional area as early as about 3 days after wounding. Such a distinct positive reaction could be observed in 3 out of 10 cases $(30 \%)$ with a wound age between 2 and 3 days. In all skin wounds with a survival time of 5 days or more, a strong positive reaction was observed in the form of a network-like structure with the exception of the oldest wounds investigated (wound age 2.5 or 7 months). Negative results were obtained in 2 out of 6 $(33 \%)$ skin wounds aged between 4 and 5 days; in one of these cases a questionable reaction was found.

Tenascin was also detectable in the granulation tissue of older wounds (wound age 1.5 months) but in reduced amounts. In 3 out of 5 cases (60\%) with a wound age of 1.5 months or more, no reactivity for tenascin was detectable in the scar tissue. However, the capillaries in the scar tissue showed positive staining.

There were no relevant differences in the time-dependent localization of tenascin between stab wounds, surgical wounds and lacerations.

In our series, no significant delay in the earliest appearance of tenascin was detectable in skin wounds obtained from older subjects, as compared to lesions from younger subjects, even though in some cases of advanced individual age a somewhat reduced staining intensity for this protein occurred. 


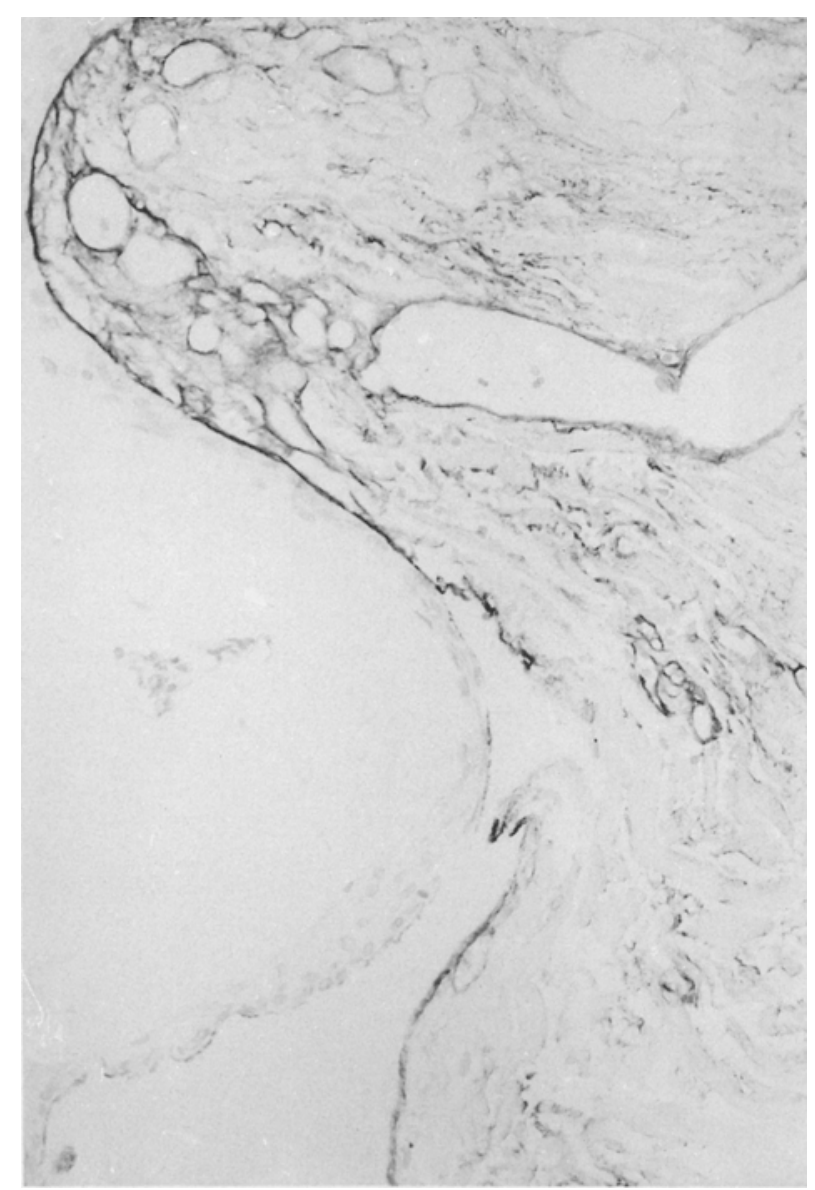

Fig. 2. Enhanced expression of tenascin at dermal-epidermal junction and in adjacent connective tissue of the wound edge of an 11day-old skin wound (paraffin wax, $240 \times$, ABC-method).

\section{Discussion}

Tenascin is an extracellular matrix protein mainly expressed during morphogenesis in embryonal life $[1,2,8$, $9,15,20,22,27]$. It reappears in malignant tumors [27], during inflammation and tissue repair, and plays a distinctive role in cell adhesion $[5,10,17,18]$. Furthermore, tenascin exerts immunomodulatory activities by altering the adhesion properties of monocytes, B- and Tcells [25]. Tenascin contains domains homologous to epidermal growth factor, fibronectin type III repeat sequence, and beta and gamma chains of fibrinogen [16, 24], suggesting similar properties to growth factors and adhesion molecules. Since it has been shown that tenascin stimulates cell proliferation in cell cultures, a mitotic signal function is also under discussion [9]. Tenascin may facilitate cell migration, and antibodies against tenascin inhibit cell migration of cerebellar granular cells [12] or during the development of the neural crest in the chick [6].

These functions indicate an important role during biological processes and an enhanced expression during wound healing has been shown in experimental animals $[11,21,23]$.

Tenascin was detected first 1-3 days after wounding in the healing skin of the mouse $[11,23]$. In rat skin wounds tenascin could be found after a similar time period [21]. Tenascin disappeared in mouse skin lesions approximately 10-14 days after. wounding and was still present in rat granulation tissue close to the dermal-epidermal junction in 10-day-old wounds.

Mackie et al. [21] found that tenascin was not detectable in the vessel walls of newly formed capillaries which appeared in the granulation tissue.

In our series, tenascin was first detectable pericellularly, around fibroblasts in the wound area of skin wounds aged approximately 2 days and therefore considerably later than another cell adhesion protein, fibronectin, which was shown to appear first after a survival time of at least a few minutes [4]. Network-like structures were observed in 3-day-old skin lesions and such a staining pattern was seen in all cases with a wound age of 5 days or more, with the exception of the oldest wounds (post infliction interval 2.5 or 7 months). These results are similar to findings reported for experimental animals $[11,21,23]$, and the regular occurrence of tenascin in skin wounds of a certain age is comparable to the staining pattern of fibronectin [4]. According to the experimental findings of Mackie et al. [21] and Chuong and Chen [11], tenascin seems to disappear at the point in time when fibronectin is still present in the granulation tissue [4].

Although a decrease in staining intensity occurred in our series with advanced wound age, tenascin was also detectable in skin wounds 1.5 months old, but could not be observed in the scar tissue of older wounds.

Differences concerning the disappearance of tenascin between the studies of Mackie et al. [21] compared to those of Chuong and Chen [11] and to our findings may be explained by the different species in which the wounds were inflicted. It may therefore be assumed that certain biological processes proceed faster in small animals than in humans, although considerable differences between experimental animals can also be noticed [11].

With respect to a possible influence of individual age or the way the wounds were inflicted (sharp or blunt trauma), we analyzed our material for differences in the time-dependent appearance of tenascin in the wound area. In some cases with advanced individual age we noticed a somewhat reduced staining intensity for this cell adhesion protein, but relevant differences, which have to be considered for a forensically applicable wound age estimation, could not be found. Berg [3] reported that the individual age influences, in particular, later changes in wound healing, but is of less importance for the beginning of reparative changes. Furthermore, the kind of lesion (stab/surgical wounds versus lacerations) also seems to have less influence on the earliest appearance of tenascin (and probably of other reparative changes) since tissue regeneration starts in particular from undamaged skin. On the other hand, it can be expected that the made of wound infliction influences as the extent of the lesional area - the interval in which tenascin can be detected since a reduced perfusion of the wound area due to edema following blunt trauma of the skin can influence the speed of repair. 
In summary, our results support the assumption that tenascin plays an important role during wound healing. The immunohistochemical localization of this extracellular matrix protein provides the following information for a forensically applicable time-estimation of human skin wounds:

1. Tenascin first appears approximately 2 days after wounding around the fibroblastic cells of the wound area.

2. Network-like structures positively staining for tenascin can first be expected in wounds with an age of 3 days or more and seem to occur regularly in lesions with an age of 5 days or more.

3. Staining intensity for tenascin decreases in granulation tissue with increasing wound age, but is still present in skin wounds of about 1.5 months. Since the extent of the lesional area influences the time period necessary for total healing to occur, a lack of positive reactivity in the granulation tissue cannot provide further information useful for a time estimation of skin lesions of advanced wound age.

Acknowledgements. This study was supported by grants from the "Deutsche Forschungsgemeinschaft" (grant Be 1555/1-1 and Be 1555/1-2) and from the "Friedrich-Baur-Stiftung", University of Munich.

\section{References}

1. Aufderheide $\mathrm{E}$, Ekblom $\mathrm{P}$ (1988) Tenascin during gut development: appearance in the mesenchyme, shift in molecular forms and dependence on epithelial-mesenchymal interactions. J Cell Biol 107:2341-2349

2. Aufderheide E, Chiquet-Ehrismann R, Ekblom P (1987) Epithelial-mesenchymal interactions in the developing kidney lead to the expression of tenascin in the mesenchyme. $J$ Cell Biol $105: 599-608$

3. Berg S (1975) Vitale Reaktionen und Zeitschätzungen. In: Mueller B (Hrsg) Gerichtliche Medizin, Bd. 1. Springer, Berlin Heidelberg New York, pp 326-340

4. Betz P, Nerlich A, Wilske J, Tübel J, Wiest I, Penning R, Eisenmenger W (1992) Immunohistochemical localization of fibronectin as a tool for the age determination of human skin wounds. Int J Leg Med 105:21-26

5. Bourdon MA, Ruoslahti E (1989) Tenascin mediates cell attachment through an RGD-dependent receptor. J Cell Biol 108:1149-1155

6. Bronner-Fraser M (1988) Distribution and function of tenascin during cranial neural crest development in the chick. J Neurosci Res 21:135-147

7. Chiquet-Ehrismann R (1990) What distinguishes tenascin from fibronectin? FASEB J 4:2598-2604

8. Chiquet M, Fambrough DM (1984) Chick myotendinous antigen. I. A monoclonal antibody as a marker for tendon and muscle morphogenesis. J Cell Biol 98: 1926-1936

9. Chiquet M, Fambrough DM (1984) Chick myotendinous antigen. II. A novel extracellular glycoprotein complex consisting of large disulfide-linked subunits. J Cell Biol 98:1937-1946
10. Chiquet-Ehrismann R, Kalla P, Pearson CA, Beck K, Chiquet M (1988) Tenascin interferes with fibronectin action. Cell $53: 383-390$

11. Chuong CM, Chen $\mathrm{HH}$ (1991) Enhanced expression of neural cell adhesion molecules and tenascin (cytotactin) during wound healing. Am J Pathol 138:427-440

12. Chuong CM, Crossin KL, Edelman GM (1987) Sequential expression and differential functions of multiple adhesion molecules during the formation of cerebellar cortical layers. J Cell Biol 104:331-342

13. Grinnell F, Billingham RE, Burgess L (1981) Distribution of fibronectin during wound healing in vivo. J Invest Dermatol $76: 181-189$

14. Hsu SM, Raine L, Fanger H (1981) A comparative study of the peroxidase-antiperoxidase method and an avidin-biotin complex method for studying polypeptide hormones with radio immunoassay antibodies Am J Clin Pathol 75:734-739

15. Inaguma Y, Kusakabe M, Mackie EJ, Pearson CA, ChiquetEhrismann R, Sakakura T (1988) Epithelial induction of stromal tenascin in the mouse mammary gland: from embryogenesis to carcinogenesis. Dev Biol 128:245-255

16. Jones FS, Burgoon MP, Hoffmann S, Crossin KL, Cunningham BA, Edelman GM (1988) A cDNA clone for cytotactin contains sequences similar to epidermal growth factor-like repeats and segments of fibronectin and fibrinogen. Proc Natl Acad Sci USA 85:2186-2190

17. Kruse J, Keilhauer G, Faissner A, Timpl R, Schachner M (1985) The J1 glycoprotein: a novel nervous system cell adhesion molecule for the L2/HNK-1 family. Nature 316:146-148

18. Lightner VA, Erickson HP (1990) Binding of hexabrachion (tenascin) to the extracellular matrix and substratum and its effect on cell adhesion. J Cell Sci $95: 263-277$

19. Lightner VA, Gumkowski F, Bigner DD, Erickson HP (1989) Tenascin/hexabrachion in human skin: biochemical identification and localization by light and electron microscopy. J Cell Biol 108:2483-2493

20. Mackie EJ, Thesleff I, Chiquet-Ehrismann R (1987) Tenascin is associated with chondrogenic and osteogenic differentiation in vivo and promotes chondrogenesis in vitro. $\mathrm{J}$ Cell Biol $105: 2569-2579$

21. Mackie EJ, Halfter W, Liverani D (1988) Induction of tenascin in healing wounds. J Cell Biol 107:2757-2767

22. Maier A, Mayne R (1987) Distribution of connective tissue proteins in chick muscle spindles as revealed by monoclonal antibodies: a unique distribution of brachionectin/tenascin. Am J Anat 180:226-236

23. Murakami R, Yamaoka I, Sakakura T (1989) Appearance of tenascin in healing skin of the mouse: possible involvement in seaming of wound tissues. Int J Dev Biol 33:439-444

24. Pearson CA, Pearson D, Shibahara S, Hofsteenge J, ChiquetEhrismann R (1988) Tenascin: cDNA cloning and induction by TGF-B. EMBO J 7:2677-2981

25. Ruegg CR, Chiquet-Ehrismann R, Alkan SS (1989) Tenascin, an extracellular matrix protein, exerts immunomodulatory activities. Proc Natl Acad Sci USA 86:7437-7441

26. Stamp GWH (189) Tenascin distribution in basal cell carcinomas. J Pathol 159:225-229

27. Thesleff I, Mackie I, Vainio S, Chiquet-Erismann R (1987) Changes in the distribution of tenascin during tooth development. Development 101:289-296 